\title{
Psychological Contract Fulfillment on Employees Reactions within the Context of Organizational Justice
}

Dr. Ch. Abdul Khaliq

Kashif Mehmood

Aamir Zamir Kamboh

Kainat Durani

Muhammad Haidar Zarar

Shaheen Nazar

Article History

Received 2019-03-20

Accepted 2019-03-28

Published 2019-04-18

Keywords

Psychological Contract

Employee Reaction

Organizational Justice

How to cite?

Khaliq, A., Mehmood, K, Kamboh, A.

Z., Durani, K., Zarar, M. H., \& Nazar,

S. (2019). Psychological Contract

Fulfillment on Employees Reactions within

the Context of Organizational Justice.

SEISENSE Journal of Management,

2(3), 42-57. doi:

bttps:// doi.org/10.33215/sjom.v2i3.131

Copyright (C) 2019 The Author(s)

\section{(cc) BY}

Superior University Lahore, Pakistan

Superior University Lahore, Pakistan

Superior University Lahore, Pakistan

Superior University Lahore, Pakistan

Superior University Lahore, Pakistan

Superior University Lahore, Pakistan 


\section{Introduction}

In a modern business environment, a firm finds itself struggling to implement its human resources effectively and efficiently. This is done to become more competitive in an environment that is very difficult to compete in, therefore this is not astonishing that relationship of employee's with the organization has recurrently emerged as a major curiosity for executives and researcher (Capelli, 1999; Ehrlich, 1994; D. Rousseau, 1995; Tsui, Pearce, Porter, \& Hite, 1995). Psychological contracts in any organization are made up of the employees' and the beliefs are considered as a shared obligation in between personnel and their respective firm lay at the grounds of a successful employment relationship (D. M. Rousseau, 1989; Schein, 1965). Yet the diversity of changes, such as downsizing of staff, restructuring of the organization, increased belief on part-time workers, international competition and demographic diversity are having thoughtful effects on employees' psychological contracts (Morrison, 1994; Turnley, Bolino, Lester, \& Bloodgood, 2003).

These changes will affect the employee in a manner of ways. These effects will have a corresponding effect on the employee's reaction. These reactions are based on the emotional and logical evaluation by the employee. These evaluations can be based on reality or perception of the employee on the environment they are subjected too. Prior research has presented considerably more confirmation that aggregate of organizational justice in management choices concerning personnel corresponds right towards the quality of consequential social interchange relations between the organization and the employee. These relationships have been shown to be an effective and significant conjecturer of employee behaviors and responses (Russell Cropanzano \& Mitchell, 2005; Rupp \& Cropanzano, 2002). In this research the impact that the psychological contract and its fulfillment have on the reaction of the employee in the context of organizational justice.

\section{Research Objective}

The aim of our research is to identify the psychological contract's expectations by employees and the impact of any deviation from its perceived benefits by the employees of an organization, as they occur within social exchange relationships to account for employee responses.

The research objectives of this research are to answer the following points, as presented below,

1. To describe the fundamentals of psychological contracts and it constitutes components.

2. To determine the criteria by which a contract is considered as fulfilled or violated in the mind of the employee.

3. To establish a direct link between the previous points with the reaction of the employee.

4. To establish a comprehensive understanding of the effect that organizational justice has on the situation.

5. To compare the difference between perception and reality and the different results of these situations.

6. To analyses the links between the three factors when they are applied together in an organization.

\section{Literature Review}

\section{Psychological Contract}

Psychological contract, concepts were introduced in the 1960s by (Levinson, Price, Munden, Mandl, \& Solley, 1962; Schein, 1965). In their hypothesis, they argued that psychological contract can be defined as expectations by the contractor, otherwise also known as the employer and the contracted, which is the 
employee about the mutual responsibilities that comprise a relationship of benefit exchange between firm and employee.

In our point of view, obligations are defined as 'beliefs', apprehended by an employer or employee, that everyone is bound by debt or promise to action or passage of the act in relationship with the other organization. Obligations may be derived by explicit or implicit promises of future interchange or reciprocity, but our concept is nevertheless an inherently perceptual one (Farnsworth, 1982). Everyone holds his/her own observation on defining a relationship of mutual obligations. It is valuable to consider social phenomena to understand perceived employment obligations, with which they are tangled. The psychological contract is a set of beliefs alleged by all the organizations in a contract about what they are eligible to collect and obligated to give interchange for one another's contributions by (Levinson et al., 1962).

Many studies have been carried out by distinguished scholars. Early works were not detailed on psychological contracts, with some implications that psychological contracts are consist of conjoint perceptions of reciprocal obligations between all entities involved in a contract (Kotter, 1973; Levinson et al., 1962; Schein, 1965).

In advanced research, it is more detailed and emphasized the numerous sides of psychological contracts that differentiate psychological contracts from related earlier constructs.

Firstly, the distinctive and perceptual essence of psychological contracts has been explained in detail, with scholarly examiners stressing that a worker's beliefs about the responsibilities underlying his/her occupational relationship are not necessarily shared by firm's agents i.e. the employer (Lucero \& Allen, 1994; Parks \& Schmedemann, 1994; D. M. Rousseau, 1989; Shore \& Tetrick, 1994). Nonetheless, a clear discrepancy between the expectation of employee(s) and the employer's perception may not be mutually shared (D. M. Rousseau, 1989). This is particularly true for implied contracts, which are shared or commonly understood expectations by involved parties in the contract. Another feature has been highlighted is that psychological contracts are grounded on perceived promises, wherever a 'promise' is explained as any communication of future intent (D. M. Rousseau, 1989).

According to Maslow's Theory of Employee Needs, published in 1943 under the title "A Theory of Human Motivation", he argued that employees have some needs, which may be expected in general. This is done in order to fulfill these needs an employee will enter into a contract with an organization. The organization will then specify in a contract, which of the needs are covered and will be fulfilled from the below-provided hierarchy pyramid.

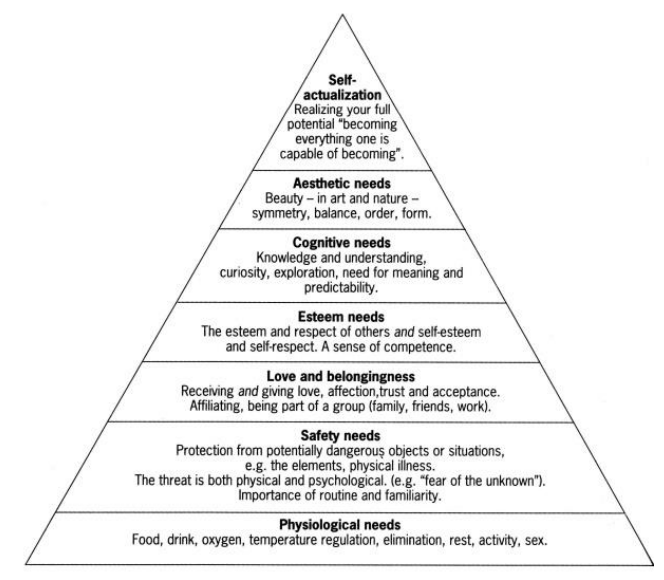

Figure 1 - Maslow's Theory of Employee Need 
Scholars have also underlined that psychological contracts are apprehended by employee(s), on behalf of members' beliefs about responsibilities between the employee(s) and the firm rather than any definite mediator of the party (Levinson et al., 1962; D. M. Rousseau, 1989; Schein, 1965). This means the business accepts the contractual attributes in the views of the employee.

\section{Contract Types}

Finally, the different types of contracts entail different psychological expectation from the employee(s).

Verbal Contract is agreements that are not written down in a hard form but is none the less considered binding by the involved parties.

Transactional Contract is a type which is limited and is linked to a process or action is short term and usually monetize able obligation.

Relational Contract is which is longer term and open-ended obligation. These are constructed on not individually by monetize able elements, such as payment on services, but also socio-emotional elements such as faithfulness and other forms of support (Parks \& Schmedemann, 1994; D. M. Rousseau \& McLean Parks, 1993).

These distinctions have suggestions for employees' responses on the probability of an employee's recognizing that their contract has been violated

To conclude, a psychological contract is explained as the personnel's belief of the conjoint responsibilities amongst that employee(s) and their firm, where these responsibilities/compulsions are founded on the perceived promise(s) and are not essentially predictable by representatives of the party.

In further discussion, we must differentiate between contractual violations and perceived breach of contracts. Significant amount of the body of work on psychological contracts, as a sample, it has been comprehensive on the essence of psychological contracts and how psychological contracts are being shaped (Parks \& Schmedemann, 1994; D. M. Rousseau \& Greller, 1994; D. M. Rousseau \& McLean Parks, 1993; Shore \& Tetrick, 1994).

\section{Contractual violation}

These are situations when the written document or verbal agreements between the employee and the organization are not fulfilled, either in a word or in spirit.

Actual breach of a contract occurs when one or more parties fail to fulfill their obligations as stipulated in the contractual contract.

Perceived Breach, on the other hand, signifies to the understanding of one's party that has unsuccessful to meet one or additional of its compulsions within one's psychological contract in a way equal to the one having provided influences. Hence, Tang and Sarsfield-Baldwin (1996) perceived breach exemplifies an intellectual valuation of indenture self-actualization that is based on personal observation of what every firm has assured and provided to the other.

Minor Breaches also knew as the partial breach is a non-severe violation of an agreement that does not stray into the material breach. Basically, an employee may pursue an internal and external course to enforce fulfillment of contract but they would not be excused from further service to their organization.

Material Breach is any failure of performance that compels the involved parties to either to enforce performance and/or terminate the contract and/or sue for damages. 
Basically, a material breach is a contractual firm's inability to accomplish an integral portion of the agreement. The purpose of the breach is to avoid the contract from being completed and/or defeats the contract and the breach is significant. A non-breaching contractual firm is therefore no longer responsible to complete their performance under the agreement.

Fundamental Breach is a violation of the contracts core aspects, also known as a repudiator violation this is a breach so elemental that it allows the non-violated firms to terminate execution of the contract and stop their obligations to the party that has violated the contract, in addition to labeling that party to plead for damages.

In conclusion, when an agreement is not fulfilled it is considered void by the employee (aggrieved party in this research), whether or not the law considers it as a violation. In conclusion, when an agreement is not fulfilled it is considered void by the employee (aggrieved party in this research), whether or not the law considers it as a violation.

\section{Employee Reaction}

This is the response that the workers or labor have to any organizational stimuli. In the area of Psychology, there exist two paradigms which are there to make understanding that how personnel evaluates justice.

First is the justice prototype, which suggests that workers assess a certain occurrence based on the specified interval and situation. This is also extended to the contractual obligation that the organization has agreed to with the employee.

The second paradigm is the social establishment paradigm; this proposed that personnel assess the social establishments, e.g. employer is considered as accountable for the occurrence and therefore impartiality observations is the overall ability of individuals to perform impartial attitudes. Managers and the organization are the insight for two social individuals particularly related to employees' global justice. Individuals are able to fully understand about employee's reactions to the moral of occurrences by mixing these paradigms.

Personnel may have different understanding on how rational their organization and employer are, even though personnel may practice some occurrences, fair or unfair, the variation in their responses may base on their pioneer observation of the societal establishments involved, this is called "Expectancy Theory". Expectancy theory is an analysis of an individual's expectation of the effort that they expend. Basically, this argues that in return of effort an individual is rewards and benefits by the party that gains from the effort expended.

However, Scholl (1981) argued that loyalty and commitment are independent forces and continues to define that commitment and loyalty factors that are independent of behavior and expectancy. These measures are investment, reciprocity, lack of alternatives and identification. "Theory of Planned Behavior" by (Ajzen, 1991; Fishbein, 1967) is the most widespread theory of human behavior.

This theory basically was developed as an extension on the "Theory of Research Action", its goal was to study human attitude and intervene in those behavior patterns in order to guide them. The foundational argument of this assumption is that actual behavior is a consequence of behavioral intentions. The commitment of intention to undertake a specific attitude i.e. attitude is a purpose of 'Subjective Beliefs' or 'Normative beliefs', both these are formed by a set of emotional and rational evaluation of the individual's beliefs.

The first type of behavioral belief is 'Subjective Beliefs', these are the individual's belief that a certain behavior of interest, such as work will result in a certain outcome. In short, this argues that the individual has an attitude of expected outcome for their effort. 
The second behavioral belief is, 'Normative Beliefs', these refer to the perceived expectation of others, such as fellow employees, etc. In short, this argues that an individual has the motivation to not their significant other's contract and agreement to be honored as well.

In review, employee reactions are based on the type of contract that the individual believes that they have entered into, i.e. verbal, transactional or relational.

The reaction of the employee is based on the return that they receive for their effort on behalf of the employer. Whether these returns are economic, socio-economic or socio-emotional, a contract exists between individuals that are engaged in economic exchange and the environment in which they operate must also comply with their beliefs.

The reaction of the employee is based on the determination of employee of whether the contract is fulfilled for them and their significant others.

\section{Organizational Justice}

This is the fairness or equity that is experienced by the employee from the organization.

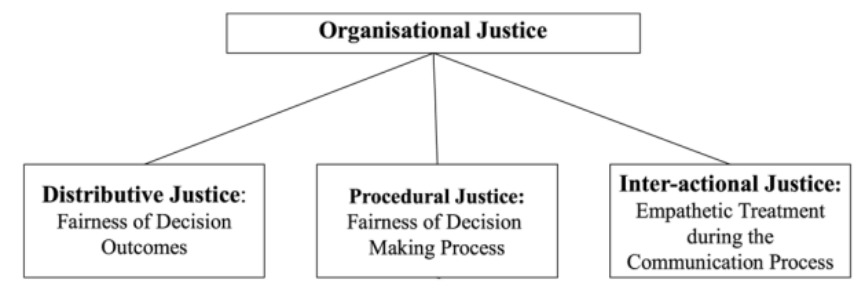

Figure 2 - Organizational Justice

Distributive Justice addresses how material rewards and benefits are spread out in an organization. Equal work should have equal rewards and benefits. Most of the researchers are in agreement that this type of justice helps in ascending an organization's efficiency (Tang \& Sarsfield-Baldwin, 1996).

Procedural Justice addresses the idea of equity in the method by which disputes are resolved and resources are allocated in an organization. Procedural justice emphases in the righteous manner through which the decision-making process is conducted (Folger \& Konovsky, 1989).

Interactional Justice was defined by Schermerhorn Jr (1975) as to how individuals react or behave when treated with respect and dignity. This is divided into two parts, interpersonal and informational justice.

Interpersonal justice is described as the style an individual is treated by their superiors. This treatment is often called dignity, respect, motivation, reassurance, etc.

Informational justice is described as the descriptions given to employees regarding why a procedure is to do this way or why results are disseminated in a certain manner. According to Coleman, most of our existence is spent around or in social institutions, such as offices, schools, courts. We interact with society on a regular basis.

In order for this arrangement to be functional measures have to be taken for interpersonal cooperation between involved entities; participants may have to pay a definite price in their slot, effort, and taxes. In return, organizations permit us to get various tangible and non-tangible advantages. Predominantly speaking researchers have arranged these benefits into two insecure categories; they are economic and socio-emotional in nature (R Cropanzano \& Schminke, 1997; Foa \& Foa, 1974; Konovsky, Folger, \& Cropanzano, 1987). 
Economic justice's benefits, also called contributory justice paybacks are those which have to deal with material comfort, well-being, and standards of existing. They are liable to be easily convertible to money and are specifically solid.

Socio-emotional benefits are the one that assigns to one's upright in and recognition with a group. Socioemotional benefits are sometimes called figurative benefits because organizations provide a manifestation of individuals' value and status within the framework of some societal group. Of course, monetary and socioemotional possessions are closely related.

Equity theory by (Adams, 1963, 1965) analyses exchanges, disagreement and comparison theories in making future forecasts about how entities accomplish their relationships with others.

Individuals assess their connections with others by matching their ratio of input to outcomes against the ratio of outcome to the input of others. If that ratio is not apparent to be relatively equal, then inequality exists. The higher the disparity the individual perceives the more distress it will create. The greater the stress on an individual feels the more effort they will expand on correcting that unequal status in order to reduce the distress or terminate that relationship.

In conclusion, 'Organizational Justice' will have a concrete effect on the employee, either positive or negative, based on the evaluation of the organization's equity position on the employee and their fellow workers.

\section{Literature Review Conclusion}

From the literature review, many factors affect the employee's reaction when it comes to psychological contract fulfillment in the framework of organizational justice.

These reactions are based on logical and emotional evaluation of the organization's treatment of them and the one around them. Whether the evaluation is based in reality or is just a perception of the lack of contractual fulfillment, an effect will be induced and felt by the organization. Any breach of the contract is a failure of organizational justice expectations by the employee.

\section{Hypothesis}

In this section, the hypothesis for the research project is developed and outlined. These are based on the information collected in the literature review section (Refer Previous Section) and are designed to conclude tangible quantitative data in the data analysis \& interpretation section of the article.

\section{Psychological Contract Fulfillment \& Employee Reaction (Hypothesis 01)}

From the literature review, psychological contract fulfillment is a utility of the organization, that employee's a worker. Levinson et al. (1962), describes psychological contract as a collection of beliefs held by every organization in a contract about what they are authorized to collect and appreciative to give in return for one another's contributions. These expectations or beliefs can be based on verbal, transactional or relational. Fulfillment, on the other hand, is the meeting of obligations.

Employee reaction, from the previous literature review, describes the response that the employee has to the activities around them. Expectancy theory is an analysis of an individual's expectation of the effort that they expend. Basically, this argues that in return of effort an individual is rewards and benefits by the party that gains from the effort expended.

However, Scholl (1981) argued that loyalty and commitment are independent forces and continues to define that commitment and loyalty factors that are independent of behavior and expectancy. These measures are investment, reciprocity, lack of alternatives and identification. The reaction of the employee is based on the 
determination of employee of whether the contract is fulfilled for them and their significant others. This reaction can be based on subjective or normative beliefs.

H 01: Psychological Contract Fulfillment (PCF) has a positive effect on Employee Reaction (ER).

Psychological Contract Fulfillment (PCF) has a positive effect on Employee Reaction (ER).

\section{Organizational Justice \& Employee Reaction (Hypothesis 02)}

From the literature review, according to Coleman, most of our existence is spent around or in social institutions, such as offices, schools, courts. We interact with society on a regular basis.

In order for this arrangement to be functional measures have to be taken for interpersonal cooperation between involved entities; participants may have to pay a specific amount in their effort, time and tariffs. In return, organizations permit us to acquire several tangible and non-tangible benefits.

Equity theory by (Adams, 1963, 1965) analyses exchanges, disagreement and comparison theories in making future estimates that how persons in organizations build and manages their relations with others.

Individual entities gage their relations with others by matching their ratio of input to outcomes against the ratio of outcome to the input of others. If that ratio is not supposed to be relatively equal, then injustice exists. The higher the disparity the individual observes the more distress it will create. The greater the stress on an individual feels the more effort they will expand on correcting that unequal status in order to reduce the distress or terminate that relationship.

Employee reaction is the response that the workers or labor have to any organizational stimuli. There are two paradigms in the area of Psychology, that occur which attempt to know how employees appraise justice.

Personnel can have contradictory perceptions of in what way impartial their supervisor or organization is thus, either personnel might practice a related experience, unbiased or not, their responses differ centered on their prior understanding of the societal entities involved, this is called "Expectancy Theory".

Expectancy theory is an analysis of an individual's expectation of the effort that they expend. Basically, this argues that in return of effort an individual is rewards and benefits by the party that gains from the effort expended.

H 02: Organizational Justice (OJ) has a positive effect on Employee Reaction (ER).

\section{Mediation of Organizational Justice between Psychological Contract Fulfillment \& Employee Reaction (Hypothesis 03)}

From the literature review justice, psychological contract fulfillment is a function of the mediation role of organizational justice.

Organizational justice is the fairness or equity that is experienced by the employee from the organization. This can be broadly categorized as economic or social justice. Also, this type of justice is distributed in three methods distributive, procedural \& interactional justice.

Psychological contract fulfillment, from the previous literature review, describes the completion of the obligation of the organization to its employees.

Levinson et al. (1962), described psychological contract as a set of philosophies held by every organization in a contract about what they are authorized to gain and obligated to give in return for one an other's contributions. 
Employee reaction, from the previous literature review, describes the response that the employee has to the activities around them.

The reaction of the employee is based on the return that they receive for their effort on behalf of the employer. Whether these returns are economic, socio-economic or socio-emotional, a contract exists between individuals that are engaged in economic exchange and the environment in which they operate must also comply with their beliefs.

The reaction of the employee is based on the determination of employee of whether the contract is fulfilled for them and their significant others.

H 03: Organizational Justice (OJ) mediates the relation between Psychological Contract Fulfillment (PCF) and Employee Reaction (ER).

\section{Research Model}

\section{Variable}

A variable in research is an event, idea, object, time period, feeling or any additional kind of cluster you are focusing to measure. There are five categories of variables in research independent, dependent, mediating, moderating and control variables.

\section{Independent Variable}

Independent variable is a variable that doesn't depend on any other variable it doesn't change or fluctuate by changes in other variables

In this research, it is being determined that what impact is psychological contract fulfillment is having on the reaction of the employee in the context of Organizational Justice.

On the analysis of the research question, it is clear that "Psychological Contract Fulfillment" is the independent variable.

\section{Dependent Variable:}

The dependent variable is a variable examined in a specific experiment and it fluctuates due to its dependence on the independent variable that is why it is known as 'dependent'. With the changes in the independent variable, the dependent variable also changes itself which is perceived and documented.

In this research, it is being determined that what impact is psychological contract fulfillment is having on the reaction of the employee in the context of Organizational Justice.

On the analysis of the research question, it is clear that "Employee Reaction" is the dependent variable.

\section{Mediating Variable}

A mediating variable is a variable that intervenes in between the dependent variables and the independent variables. In additional words, the mediator explains the relation between both the dependent variable and the independent variable. A complete mediation defined as a process of complete intervention caused by mediator variable. According to research, it is being determined that what impact is psychological contract fulfillment is having on the reaction of the employee in the context of Organizational Justice.

On the analysis of the research question, it is clear that "Organizational Justice" is the Mediating variable. 


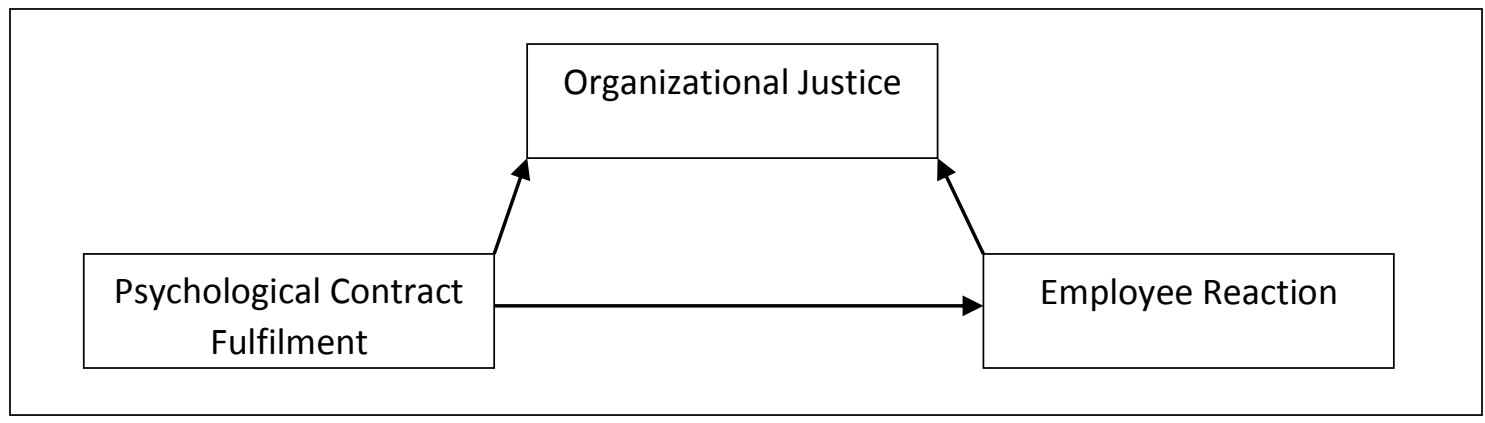

Figure 3 - Research Model

\section{Measures \& Questionnaire Design}

\section{Measures}

The questionnaire was distributed to 190 individuals in a wide range of organization and professional educational institutions. 188 surveys were filled to research satisfaction.

The survey was conducted for domestic organizations operating all over Pakistan in the services industries. All those who were surveyed were employed at the moment that the survey was conducted. For further data, please refer to the Data Analysis \& Interpretation section of this article.

The measurement questionnaire was developed from the previous works of the following individuals:

- (Robinson \& Rousseau, 1994)

- (Freese \& Schalk, 2008)

- (Schalk \& Freese, 1997)

- (Thomas \& Anderson, 1998)

- (Turnley \& Feldman, 1999)

- (Robinson \& Wolfe Morrison, 2000)

- (Coyle-Shapiro \& Kessler, 2002)

- (Kickul, Lester, \& Finkl, 2002)

- (Conway \& Briner, 2002)

- (Guest \& Conway, 2002)

- (Tekleab \& Taylor, 2003)

- (Ten Brink, 2004)

These survey questionnaires are the premier sources of questions developed and used by the research community for this type of research.

\section{Questionnaire Design}

- Psychological Contract (PCF)

This part has 14 questions in total representing different elements of the internal variables. 10 questions of this part are tested using a five-point Likert scale, with ' 1 ' representing "Strongly Disagree" and '5' 
representing "Strongly Agree". 4 questions of this part are a dichotomous scale, with a "Yes" and "No" answer options.

- Employee Reaction (ER)

This part has 12 questions in total representing different elements of the internal variables. 9 questions of this part are measured using a five-point Likert scale, with ' 1 ' representing "Strongly Disagree" and "5' representing "Strongly Agree". 3 question of this part is a dichotomous scale, with a "Yes" and "No" answering options.

- Organizational Justice (OJ)

This part has 9 questions in total representing different elements of the internal variables. Five-point Likert scale is used to measure 6 questions of this part, with "1'representing "Strongly Disagree" and "5'representing "Strongly Agree". 3 question of this part is a dichotomous scale, with a "Yes" and "No" answering options.

\section{Data Analysis \& Interpretation}

\section{Confirmatory Factor Analysis}

Factor loadings are there to analyze the convergent validity of construct it is composite reliability and average variance extract. The validity of constructs is considered to be convergent when items/indicators load results high $(>0.50)$ on their subordinate constructs Joseph F Hair, Anderson, Babin, and Black (2010) and outcomes indicate that factor loadings values are greater than (0.50). Average composite reliability and variance extract are used to measure convergent validity of constructs. The AVE values of all items are above (0.50), and composite reliability is higher than (0.8), representing that convergent validity of all constructs has been established.

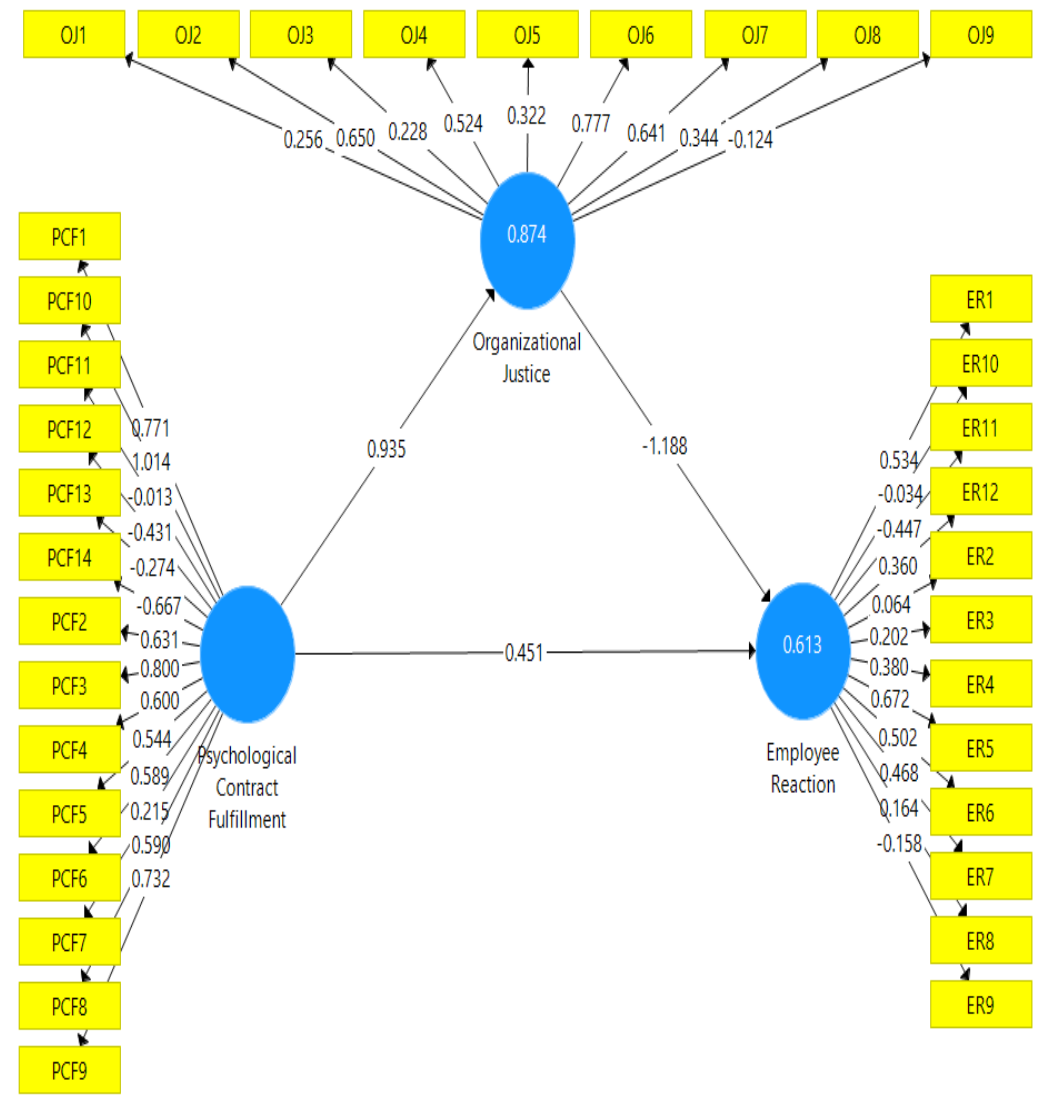

Figure 4 - Confirmatory Factor Analysis 
Table 1 - Factor Analysis

\begin{tabular}{|c|c|c|c|c|c|}
\hline Constructs & & Loadings & Alpha & AVE & CR \\
\hline \multirow[t]{14}{*}{ Psychological Contract Fulfillment } & PCF1 & 0.79 & \multirow[t]{14}{*}{0.743} & \multirow[t]{14}{*}{0.915} & \multirow[t]{14}{*}{0.776} \\
\hline & PCF2 & 0.85 & & & \\
\hline & PCF3 & 0.76 & & & \\
\hline & PCF 4 & 0.74 & & & \\
\hline & PCF 5 & 0.87 & & & \\
\hline & PCF 6 & 0.785 & & & \\
\hline & PCF 7 & 0.77 & & & \\
\hline & PCF 8 & 0.69 & & & \\
\hline & PCF 9 & 0.99 & & & \\
\hline & PCF 10 & 0.88 & & & \\
\hline & PCF 11 & 0.65 & & & \\
\hline & PCF 12 & 0.88 & & & \\
\hline & PCF 13 & 0.79 & & & \\
\hline & PCF 14 & 0.733 & & & \\
\hline \multirow[t]{12}{*}{ Employee Reaction } & ER1 & 0.89 & \multirow[t]{12}{*}{0.765} & \multirow[t]{12}{*}{0.935} & \multirow[t]{12}{*}{0.553} \\
\hline & ER2 & 0.90 & & & \\
\hline & ER3 & 0.84 & & & \\
\hline & ER4 & 0.742 & & & \\
\hline & ER5 & 0.87 & & & \\
\hline & ER6 & 0.86 & & & \\
\hline & ER7 & 0.801 & & & \\
\hline & ER8 & 0.785 & & & \\
\hline & ER9 & 0.73 & & & \\
\hline & ER10 & 0.666 & & & \\
\hline & ER11 & 0.84 & & & \\
\hline & ER12 & 0.846 & & & \\
\hline \multirow[t]{9}{*}{ Organizational Justice } & OJ1 & 0.84 & \multirow[t]{9}{*}{0.787} & \multirow[t]{9}{*}{0.905} & \multirow[t]{9}{*}{0.575} \\
\hline & $\mathrm{OJ} 2$ & 0.846 & & & \\
\hline & OJ3 & 0.783 & & & \\
\hline & OJ4 & 0.844 & & & \\
\hline & OJ5 & 0.783 & & & \\
\hline & OJ6 & 0.808 & & & \\
\hline & OJ7 & 0.561 & & & \\
\hline & OJ8 & 0.425 & & & \\
\hline & OJ9 & 0.485 & & & \\
\hline
\end{tabular}

\section{Discriminant Validity}

Table 2 shows the results related to the discriminant validity assessment of less researched variables. All the square roots of AVEs constructs are higher than the lower co-efficient or transverse elements in the equivalent rows and columns, hereafter discriminant validity has been established. 
Table 2 - Discriminant Validity

\begin{tabular}{llll}
\hline Variable & ER & OJ & PCF \\
\hline ER & 0.385 & - & \\
OJ & -0.766 & 0.479 & - \\
PCF & -0.660 & 0.035 & 0.615 \\
\hline
\end{tabular}

\section{Heterotrait - Monotrait Ratio}

Table 3 shows the HTMT ratio it is an approach to access discriminant validity that is another effective and alternative approach to determine discriminant validity. To ensure the discriminant validity HTMT ratio should be less than 0.85 and in the case of evidence of discriminant validity all the ratio values are higher than the lower threshold.

Table 3 - Heterotrait - Monotrait Ratio

\begin{tabular}{llll}
\hline Variable & ER & OJ & PCF \\
\hline ER & - & & \\
OJ & 0.750 & - & - \\
PCF & 0.703 & 0.724 & - \\
\hline
\end{tabular}

\section{Structure Equation Modeling}

Table 4 - Structure Equation Modeling

\begin{tabular}{cccccccccc}
\hline Hypothesis & Relationship & St. Beta & S.E. & t-Value & Decision & R2 & F2 & VIF & Q2 \\
\hline H1 & PCF->ER & -0.154 & 0.166 & 2.349 & Supported & 0.101 & 0.006 & 1.651 & 0.051 \\
H2 & OJ ->ER & -0.183 & 0.094 & 5.687 & Supported & 0.613 & 0.037 & 1.103 & 0.233 \\
H3 & OJ->PCF & -0.138 & 0.024 & 33.284 & Supported & 0.874 & 0.024 & 1.037 & 0.45 \\
\hline
\end{tabular}

Hypothesis 1 predicted an impact of Psychological Contract on Employee Reaction. Results concluded a significant positive impact of Psychological Contract Fulfillment on Personnel Reaction, thus supports H1 and H3. Lastly, H2 proposed the relations between Organizational Justice and Employee Reaction and results purported that organizational Justice is positively related to Employee Reaction.

Blindfolding method is used to test the predictive relevance of theoretical model (Stone, 1974). To measure the predictive relevance a cross-validated redundancy measure (Q2) was applied (Joseph F Hair, Ringle, \& Sarstedt, 2013). Q2 for research model is higher than zero that shows predictive relevance. Outcomes also analyzed that there is none multi-collinearity issue with data as the value of VIF is fewer than 5 as suggested by (Joe F Hair, Ringle, \& Sarstedt, 2011).

\section{Conclusion}

We examine the psychological contract expectations by employees and the impact of any deviation from its perceived benefits by the employees of an organization, as they occur within social exchange relationships to account for employee responses. This is an exploratory longitudinal study in which an investigation is made into the variations in employment obligations as perceived by employees based on the level of fulfillment of contract obligations by their employer(s). It was deduced that an employer's inability to fulfill its contractual commitments was the foundational cause associated with the decline in cooperation of the employees to fulfill their employment obligations. We discuss implications for providing equity to employees in an organization. 
Results presented that there is a significant and positive relationship between Psychological Contract Fulfilment and Employee Reaction supported by H1.

Results presented that there is a significant and positive relationship between Organizational Justice and Employee Reaction supported by $\mathrm{H} 2$.

Results presented that there is a significant and positive relationship between Organizational Justice and Psychological Contract Fulfilment supported by H3.

\section{References}

Adams, J. S. (1963). Towards an understanding of inequity. The Journal of Abnormal and Social Psychology, 67(5), 422.

Adams, J. S. (1965). Inequity in social exchange Advances in experimental social psychology (Vol. 2, pp. 267-299): Elsevier.

Ajzen, I. (1991). The theory of planned behavior. Organizational behavior and buman decision processes, 50(2), 179211.

Capelli, P. (1999). The new deal at work: Managing the market-driven workforce: Harvard Business School.

Conway, N., \& Briner, R. B. (2002). A daily diary study of affective responses to psychological contract breach and exceeded promises. Journal of Organizational Behavior: The International Journal of Industrial, Occupational and Organizational Psychology and Behavior, 23(3), 287-302.

Coyle-Shapiro, J. A.-M., \& Kessler, I. (2002). Exploring reciprocity through the lens of the psychological contract: Employee and employer perspectives. European journal of work and organizational psychology, 11(1), 69-86.

Cropanzano, R., \& Mitchell, M. S. (2005). Social exchange theory: An interdisciplinary review. Journal of management, 31(6), 874-900.

Cropanzano, R., \& Schminke, M. (1997). Justice as the mortar of social cohesion. Groups at work: Advances in theory and research. Hillsdale, NJ: Lawrence Erlbaum \& Associates.

Ehrlich, C. J. (1994). Creating an employer-employee relationship for the future. Human Resource Management, 33(3), 491-501.

Farnsworth, E. (1982). Policing the agreement. Contracts. Boston, Little Brown \& Co Inc, 221-223,231.

Fishbein, M. (1967). Attitude and the prediction of behavior. Readings in attitude theory and measurement.

Foa, U. G., \& Foa, E. B. (1974). Societal structures of the mind: Charles C Thomas.

Folger, R., \& Konovsky, M. A. (1989). Effects of procedural and distributive justice on reactions to pay raise decisions. Academy of Management Journal, 32(1), 115-130.

Freese, C., \& Schalk, R. (2008). How to measure the psychological contract? A critical criteria-based review of measures. South African Journal of Psychology, 38(2), 269-286. 
Guest, D. E., \& Conway, N. (2002). Communicating the psychological contract: an employer perspective. Human Resource Management Journal, 12(2), 22-38.

Hair, J. F., Anderson, R. E., Babin, B. J., \& Black, W. C. (2010). Multivariate data analysis: A global perspective (Vol. 7): Upper Saddle River, NJ: Pearson.

Hair, J. F., Ringle, C. M., \& Sarstedt, M. (2011). PLS-SEM: Indeed a silver bullet. Journal of Marketing Theory and Practice, 19(2), 139-152.

Hair, J. F., Ringle, C. M., \& Sarstedt, M. (2013). Partial least squares structural equation modeling: Rigorous applications, better results and higher acceptance. Long range planning, 46(1-2), 1-12.

Kickul, J., Lester, S. W., \& Finkl, J. (2002). Promise breaking during radical organizational change: do justice interventions make a difference? Journal of Organizational Behavior: The International Journal of Industrial, Occupational and Organizational Psychology and Behavior, 23(4), 469-488.

Konovsky, M. A., Folger, R., \& Cropanzano, R. (1987). Relative effects of procedural and distributive justice on employee attitudes. Representative research in social psychology, 17(1), 15-24.

Kotter, J. P. (1973). The psychological contract: Managing the joining-up process. California management review, 15(3), 91-99.

Levinson, H., Price, C. R., Munden, K. J., Mandl, H. J., \& Solley, C. M. (1962). Men, management, and mental health.

Lucero, M. A., \& Allen, R. E. (1994). Employee benefits: A growing source of psychological contract violations. Human Resource Management, 33(3), 425-446.

Morrison, E. W. (1994). Role definitions and organizational citizenship behavior: The importance of the employee's perspective. Academy of Management Journal, 37(6), 1543-1567.

Parks, J. M., \& Schmedemann, D. A. (1994). When promises become contracts: Implied contracts and handbook provisions on job security. Human Resource Management, 33(3), 403-423.

Robinson, S. L., \& Rousseau, D. M. (1994). Violating the psychological contract: Not the exception but the norm. Journal of Organizational Behavior, 15(3), 245-259.

Robinson, S. L., \& Wolfe Morrison, E. (2000). The development of psychological contract breach and violation: A longitudinal study. Journal of Organizational Behavior, 21(5), 525-546.

Rousseau, D. (1995). Psychological contracts in organizations: Understanding written and unwritten agreements: Sage publications.

Rousseau, D. M. (1989). Psychological and implied contracts in organizations. Employee responsibilities and rights journal, 2(2), 121-139.

Rousseau, D. M., \& Greller, M. M. (1994). Guest editors' overview: Psychological contracts and human resource practices. Human Resource Management (1986-1998), 33(3), 383. 
Rousseau, D. M., \& McLean Parks, J. (1993). The contracts of individuals and organizations. Research in organizational behavior, 15, 1-1.

Rupp, D. E., \& Cropanzano, R. (2002). The mediating effects of social exchange relationships in predicting workplace outcomes from multifoci organizational justice. Organizational behavior and buman decision processes, 89(1), 925-946.

Schalk, R., \& Freese, C. (1997). New facets of commitment in response to organizational change: Research trends and the Dutch experience. Journal of Organizational Behavior (1986-1998), 107.

Schein, E. H. (1965). Organizational psychology.

Schermerhorn Jr, J. R. (1975). Determinants of interorganizational cooperation. Academy of Management Journal, 18(4), 846-856.

Scholl, R. W. (1981). Differentiating organizational commitment from expectancy as a motivating force. Academy of Management Review, 6(4), 589-599.

Shore, L., \& Tetrick, L. (1994). The psychological contract as an explanatory framework'. Trends in organizational behavior, 1, 91-109.

Tang, T. L.-P., \& Sarsfield-Baldwin, L. J. (1996). Distributive and procedural justice as related to satisfaction and commitment.

Tekleab, A. G., \& Taylor, M. S. (2003). Aren't there two parties in an employment relationship? Antecedents and consequences of organization-employee agreement on contract obligations and violations. Journal of Organizational Behavior: The International Journal of Industrial, Occupational and Organizational Psychology and Behavior, 24(5), 585-608.

Ten Brink, B. E. H. (2004). Psychological contract: a useful concept?

Thomas, H. D., \& Anderson, N. (1998). Changes in newcomers' psychological contracts during organizational socialization: A study of recruits entering the British Army. Journal of Organizational Behavior: The International Journal of Industrial, Occupational and Organizational Psychology and Behavior, 19(S1), 745-767.

Tsui, A. S., Pearce, J. L., Porter, L. W., \& Hite, J. P. (1995). Choice of employee-organization relationship: Influence of external and internal organizational factors. Research in personnel and buman resources management, 13(1), 117-151.

Turnley, W. H., Bolino, M. C., Lester, S. W., \& Bloodgood, J. M. (2003). The impact of psychological contract fulfillment on the performance of in-role and organizational citizenship behaviors. Journal of management, 29(2), 187-206.

Turnley, W. H., \& Feldman, D. C. (1999). The impact of psychological contract violations on exit, voice, loyalty, and neglect. Human Relations, 52(7), 895-922. 